\title{
Concha Zardoya: The Intellectual in Exile
}

\author{
Mónica Jato \\ University of Birmingham, Edgbaston, Birmingham, B15 2TT, UK \\ e-mail: m.jato@bham.ac.uk \\ ORCID iD: https://orcid.org/0000-0001-6834-8685
}

Submitted: 18 January 2018. Accepted: 14 September 2018

\begin{abstract}
The intellectual life of Concha Zardoya (1914-2004) was shaped significantly by its transnational dimension. While Chile was her country of birth, Spain was the place where her university education took place and the United States where her academic and intellectual career developed. The atmosphere of political repression experienced in the 1940s in Spain forced her to look for a new home in the USA. There she obtained her PhD, developing a successful academic career that spanned the next twenty-nine years of her life. Her work as a literary critic was, however, intrinsically linked to her work as a poet, which first began with the publishing of Pájaros del Nuevo Mundo in 1946. This article considers Zardoya's poetry in light of her experience as a political exile. The fact that her departure from Spain did not coincide with the mass exodus of 1939 has caused many critics to view her residence in the USA as "emigration." My analysis will focus, instead, on the exilic dimension of her work as an act of affective citizenship, paying particular attention to three books of poetry written in America: Desterrado ensueño, Corral de vivos y muertos and Hondo Sur.
\end{abstract}

KEYWORDS: Affect as site of political resistance; Affective citizenship; Exile; Female academics; Franco's Dictatorship; Spanish poetry; Worldliness.

Citation / Cómo citar este artículo: Jato, Mónica (2019) "Concha Zardoya: The Intellectual Exile" Culture \& History Digital Journal, 8 (1): e007. https://doi.org/10.3989/chdj.2019.007

RESUMEN: El exilio intelectual de Concha Zardoya.- La vida intelectual de Concha Zardoya (1914-2004) se halla marcada profundamente por su dimensión transnacional. Chile fue su país de nacimiento, España el de su formación universitaria y Estados Unidos el de su carrera académica e intelectual. El ambiente de represión política vivido en la década de los cuarenta la obligó en 1948 a buscar un nuevo hogar en la universidad norteamericana. Allí obtuvo su doctorado y desarrolló una exitosa carrera académica que ocuparía los próximos 29 años de su vida. Íntimamente ligada a su labor académica como crítica literaria se encuentran las numerosas entregas de poesía que comienzan en 1946 con Pájaros del Nuevo Mundo. El presente trabajo realiza una lectura de la obra poética de Zardoya precisamente a la luz de la experiencia de su exilio político. La falta de sincronía con el éxodo masivo de 1939 ha provocado la consiguiente percepción de su residencia en USA como "emigración” o, a lo sumo, como "expatriación." Mi análisis se centrará, en cambio, en la presencia de la experiencia del exilio en su poesía como un acto de ciudadanía afectiva, y partirá del estudio de tres poemarios escritos ya en tierras americanas: Desterrado ensueño, Corral de vivos y muertos y Hondo Sur.

PALABRAS CLAVE: Afecto como resistencia política; Ciudadanía afectiva; Dictadura franquista; Exilio; Mujeres académicas; Poesía española; Worldliness.

Copyright: (C) 2019 CSIC. This is an open-access article distributed under the terms of the Creative Commons Attribution 4.0 International (CC BY 4.0) License. 
The work of Concha Zardoya (Valparaíso 1914-Madrid 2004) continues to be excluded from the pages of Spanish literary history. ${ }^{1}$ Her numerous collections of poetry and short stories have largely been overlooked and there are few anthologies of her work or literary studies that analyse her intellectual trajectory. ${ }^{2}$ Three factors seem to have contributed to this lack of recognition or interest in the author: her gender; the fact that she wasn't born in Spain or, in other words, her contentious nationality; and finally her move to the United States in 1948 where she lived for almost thirty years, carving out a successful career as a literary critic and as a Professor of Spanish literature. As regards the first of these factors, Zardoya was no exception to the rule: as was the case for so many other women writers of the time, such as Concha Méndez, Ernestina de Champourcín, Ángela Figuera, María Beneyto, or even Carmen Conde, Zardoya never enjoyed the same popularity as her male counterparts, despite the significant literary quality of her work (Moreno, 2009: 125). The second of these factors, the fact she was born in Chile, often made it difficult for her to be categorised as a Spanish writer, despite having been legally granted Spanish nationality (Rodríguez Pequeño, 1987: 23; Persin, 2009: 119). Finally, her prolonged stay in the United States meant she was inevitably distanced from Spanish reading public; her intermittent visits to the country made little impact, nor did the publication of much of her poetry in Spain, nor the fact that she regularly collaborated with several journals (Debicki, 1994:69). ${ }^{3}$ There is, however, a fourth factor that has not been sufficiently taken into account by critics and which is vital to understanding why Zardoya's work seems not to belong to a particular place, or rather seems to find itself continually "out of place," belonging neither to Spanish literature, nor Chilean literature, and certainly not North-American literature. This factor is her controversial - and at times questioned-status as a political exile. Critics certainly recognise this status when they summarise her biography, but are quick to add that, in actual fact, given her late departure from Spain in 1948, she is more of an "expatriate" than a true "exile" (Bellver, 1991: 58). ${ }^{4}$ On other occasions, it is insinuated that there were socio-economic reasons for her exile, although these were fostered by her "inappropriate political affiliations" which would have prevented her from progressing professionally in National Catholic Spain (Pérez, 2009: 40; Moreno, 2009: 127). This persistent ambiguity concerning Zardoya's status as a political exile has been the cause of her subsequent absence or exclusion from the exile literary canon of 1939, and it helps explain why her work is little known.

Taking these factors into account, the present study considers Zardoya's poetic and essayistic work in light of her experience as a political exile. As will be shown through the letters written to her friend and mentor, the Chilean writer Gabriela Mistral, Zardoya shared the tragic destiny of so many Spaniards who were unable to leave the country in 1939 and remained trapped in Franco's Spain. This failure to join the mass exodus in 1939 conse- quently led to her stay in the USA being seen as "emigration" or, at best, "expatriation." This analysis will, however, focus on the exilic dimension of her work and examine three collections of poetry that are very different in nature but which are the result of her experience as an exile, and were written on American soil: Desterrado ensueño (Exiled Dream) (1955), Corral de vivos y muertos (Corral of the Living and the Dead) (1965) and Hondo Sur (Deep South) (1968). ${ }^{5}$ The analysis also draws on her poetic thought, expressed as a kind of manifesto in two essays of literary criticism: "El poeta político. (En torno a España)" (The Political Poet. About Spain) (1976) and "La torre inclinada" (The Leaning Tower) (1983). In these essays Zardoya reflects at length on the public role or function that the poet/intellectual must perform in society in order to serve as "the alarm clock for the conscience: for those above and those below, and those in between. Ringing honourably at the right moment" (1976: 139). Finally, this study highlights the importance of one aspect, often placed in the background or touched on only tangentially, that is key to understanding the intellectual parameters which frame a large part of Concha Zardoya's work: if her experience as a political exile is not acknowledged, it is almost impossible to grasp her quest for "painful citizenship" ("dolorosa ciudadanía") within her poetic world which, as she says in the opening epigraph to Corral de vivos y muertos, is "denied to her by some". As will be explained in the following sections, her exile is a direct consequence of the denial of citizenship which the poet suffered at the hands of the Franco dictatorship; the only way she can defend it is by wielding her words like a sword. In both prose and verse, she firmly declares that the poet is the embodiment of the "true intellectual" who, in no way, "can be an accomplice to injustice or cruelty" and who should be "a living part of the conscience of her homeland throughout her mortal life" (Zardoya, 1976: 140). ${ }^{6}$ This situation can be found in the aforementioned Corral de vivos y muertos, in which she gives an account of the daily reality of Spain in the first post-war years as a so-called inner exile, likewise echoing the feelings of nostalgia, separation and absence suffered by those who experienced "territorial exile." But this is also the case in Hondo sur, in which the pain and injustice of life during the Franco repression makes her receptive to the injustice suffered by the African-American population in the southern United States: "The Deep South, the South that I have lived in, emerges for Spain in this song. / The Spanish pain, my pain, with the pain of the South, unified!” (12).

Her poetry and critical work both defend the fact that neither the poet nor the intellectual can live locked away in an ivory tower, "knowing nothing of what happens in the society and the world around them" (1976: 139). In fact, the poet (who, for Zardoya, serves as a constant synonym for the intellectual) is obliged to "[...] keep the windows of the soul and the mind wide open, place their feet firmly on the ground beneath them" (1976: 139. My emphasis). This recurring intersection between exile, (affective) citizenship and complicity (or engagement) with 
surrounding reality is closely related to the notion of "worldliness" developed by Edward Said in The World, the Text and the Critic (1983), which in Zardoya's words becomes keeping your feet on the ground. The term "worldliness" makes reference, therefore, not only to the material contexts to which the texts belong, their way of being located in the world, but also to the actual situation or situatedness of the work of the intellectual (the critic) in a determined historical moment and his/her duty to "speak truth to power" (1983: 30) or, according to Zardoya, being a "tenacious defender of the truth" (1976: 139). ${ }^{7}$ Recognising that "texts are worldly" means accepting that "to some degree they are events, and, even when they appear to deny it, they are a part of the social world, human life, and of course the historical moments in which they are located and interpreted" (Said 1983: 4). Thus, the notion "worldliness" becomes vital in understanding the public function of the intellectual in society as: "the intellectual's capacity to say anything relevant in his or her society cannot dispense with the concept of worldliness, for without worldliness the intellectual can have no world from which, and to which, to speak" (Ashcroft and Ahluwalia, 1999: 27).

But how can the intellectual/poet speak truth to pow$e r$ ? The only way to do this is to defend freedom and embrace a marginal position within society. For Said, these qualities of the intellectual are encapsulated in the condition of exile because, in order to maintain a critical position against injustice, dispossession and the excesses of power, the only option is to "not to be at home in one's home:" "Exile for the intellectual in this metaphorical sense is restlessness, movement, constantly being unsettled, and unsettling others. You cannot go back to some earlier and perhaps more stable condition of being at home; and alas, you can never fully arrive, be at one with your new home" (Said 1994: 53). This proposition is a great paradox in Said's thinking, because, as Ashcroft and Ahluwalia point out, "it is difficult to see how far the idea of metaphoricity can be taken without dissolving the concept of exile altogether" (44). Certainly, Said's passionate defence of exile as a strictly historical condition in "The Mind of Winter: Reflections on Life in Exile," in which he states that "[m]odern exile is irremediably secular and unbearably historical" (1984: 50), is difficult to reconcile with his later celebration of the pleasures of exile, "Intellectual Exile: Expatriates and Marginals" (1994), in which he uses the term in a figurative sense. Perhaps the solution to this paradox cannot be found in the field of theoretical discussion but in its practical application. These two apparently antagonistic formulations are reconciled when we consider a case like Concha Zardoya. If there is somebody who breathes life into the model of the intellectual exile that Said had in mind it is Zardoya, although she never rejected the historical materiality of her exile: for her, the condition of exile is not a metaphor. This paradox is resolved, therefore, in her personal and poetic development. The evolution which takes place from Corral de vivos muertos to Hondo sur is one of the intellectual who has interiorised the painful but empower- ing lessons of exile brought about by the Civil War and the Franco dictatorship. This experience allows her, when she comes into contact with her new home in Louisiana, to contemplate the racial problems she encounters in light of the injustice she has experienced in her own homeland. In this way, the exile, as Said claims in his essays, never sees the reality before his/her eyes as an isolated phenomenon, but as a constant interaction with what $\mathrm{s} / \mathrm{he}$ has left behind:

Intellectually this means that an idea or experience is always counterposed with another, therefore making them both appear in a sometimes new and unpredictable light: from that juxtaposition one gets a better, perhaps even more universal idea of how to think, say, about a human rights issue in one situation by comparison with another (1994: 60).

It is from this double perspective therefore that Hondo Sur has been written, as illustrated in the previously mentioned opening of the book ("The Spanish pain, my pain, with the pain of the South, unified!"). For these reasons, Concha Zardoya can be seen to embody the model of the "intellectual exile," the only one who, according to Said, is capable of "speaking truth to power".

\section{CIVIL WAR AND EXILE}

Concha Zardoya lived in Chile until she was seventeen years old. Her Spanish parents had emigrated due to "disagreements with the monarchic and conservative government of Alfonso XII" (Perez, 2009: 38). Her childhood was nourished to a large extent by the family memories of and nostalgias for a far-away Spain, evoked from a distance. For this reason, the poet states that she experienced a "Spanish-Chilean" childhood "[...] because although her experiences were rooted in the Spanish character and way of life, they ocurred against the background of a Chilean landscape - ocean and mountain — and society" (qtd. in Rodríguez Pequeño, 1987: 36). In the daily conversations that relived the places where her parents had spent their lives - her father was from Navarra and her mother from Cantabria—she learned "Spanish intrahistory" (36). This would be Zardoya's first training in what would later become a common practice in her poetry as well as one of the favourite topics in her literary criticism: the thematization of space and landscape, that sense of spatiality that characterizes all her work (Persin, 2009: 122). During this initial stage of her education, Zardoya describes the double dimension of her identity stemming from her country of origin and the affective affiliation to the cultural legacy of her parents. In an interview with Mercedes Rodríguez she confesses how the study of Spanish literature in the Chilean Liceo taught her "a new dimension of my own life: one that was tied to Spain not only by blood, but by culture. This discovery was the start of a mission that still has not ended for me" (qtd. in Rodríguez Pequeño, 1987: 38). This was the start of her cultural hybridity, that "state of in-betweenness" that marks her whole work. 
In July 1932 Zardoya moved to Spain; her parents decided to return after the declaration of the Second Republic on $14^{\text {th }}$ April 1931. Although this was actually her first visit, the journey for her also had something of a homecoming about it, as she was returning to the spaces evoked in her imagination and the world of her first readings. As she recalls in one of her later works Diotima y sus edades (Diotima and her ages) (1981):

And my parents heard the call

of the new Republic,

and I felt, as a daughter, that my roots

were searching for old land and new air. (74)

On arrival she went firstly to Zaragoza and Barcelona, but soon the family settled permanently in Madrid where she started her degree at the Faculty of Philosophy and Letters in 1934. The first few years in Spain were not easy: to manage the economic hardships they encountered in their new home she taught in a kindergarten, gave private lessons to high school students and worked as a secretary for the poet Gabriela Mistral, who was then the Chilean consul in Madrid (Pérez 2009: 38). But her life took a radical turn with the events of $18^{\text {th }}$ July 1936 and the outbreak of the Civil War, bringing with them a time of death and destruction. In 1936 she moved to Valencia and began contributing to "Cultura Popular," which was dependent on the Ministry of Public Instruction of the Republican Government (Zardoya, 2005). In 1938 she met the poet Miguel Hernández, who she introduced to Radio Valencia where he read his latest poems, "El niño yuntero" (The Plough Boy), "Canción del esposo soldado" (Song of the Soldier Husband) "El sudor" (Sweat), and "Madrid" (Rodríguez Pequeño, 1987: 42). ${ }^{8}$ It was the beginning of a great friendship and a fascination with both the person and his work which could be seen reflected not only in the poems she dedicated to him throughout her life but also in the many studies in which she explored the human value of his works. ${ }^{9}$ For Zardoya, Miguel Hernández represented a prime example of the poet/intellectual who was committed to reality, capable of speaking truth to power and of dying to defend those values.

Zardoya's intellectual commitment to the cultural work of the Republican government was therefore absolute: "she taught classes to adults and was in charge of organising libraries for hospitals, factories and war zones; she prepared montages and collages for «diarios murales» and radio programmes, etc. with complete enthusiasm, determination and dedication" (Rodríguez Pequeño, 1987: 43). During these years she formed friendships with the writers Dámaso Alonso, Juan Gil-Albert, José María Quiroga Pla, and Pablo Neruda. This period constituted a decisive moment in her still fledgling writing career, but the tragic death of her brother was a painful blow that marked a before and after in her poetic work, as she confessed to her friend Gabriela Mistral in a letter dated $4^{\text {th }}$ January $1939: 1^{10}$

I have to tell you that your old Portuguese letters saved me from going under on so many bad days. Your belief in me gave me the strength to go on fighting, to continue living, despite the devastating news (my brother died tragically). And all that pain was poured into two books. And it awakened in me a new and real destiny that I'm willing to achieve no matter what. You don't know it yet but I have to tell you my destiny is poetry. (http://www. bibliotecanacionaldigital.cl/bnd/623/w3-article-135635. html)

The Civil War acted as a catalyst to her literary work. She started to write poetry that was deeply rooted in reality, in the historical moment in which she was immersed, or, in Said's words, a "worldly" poetry. These first two collections to which she refers in her letter are Violencia del duelo (Violence of Mourning) (1937-1938) and Memorial de la Guerra (Memorial to the War). She published two poems from the volume collection, "Antiguos camaradas (Elegía)" [Former Comrades (Elegy)] and "Ritual del pan" (Bread Ritual), in the journal Hora de España in July 1938. The two collections were then followed by Agreste voz (Wild Voice), Sólo el amor (Only Love) and Loas a una rosa (Praise for a Rose). Zardoya refused to publish these volumes as she saw them merely as a learning exercise, and all five remain unpublished to this day. This whole period of the war, however, would become decisive in her later intellectual and personal evolution: "without our war, I would not have been who I was and who I am. It defines my life, my work, and in part, my vision of the world and of man" (qtd. in Rodríguez Pequeño, 1987: 44).

If, therefore, her loyalty to the Republican cause and her personal involvement in the war was so evident, the question arises as to why Zardoya was not part of of the mass exodus of 1939? A letter to Gabriela Mistral sheds some light on the reasons why:

Finally! I'm going home, to my Chile. I've applied here for repatriation but it's taking such a long time. I've been advised I need to move things along. I'm telling you in case there's something you could do to help? The embassy, as is only natural, only deals with the application, but can't offer any other help. [...] (There are so many of us in Europe from Chile in the same situation) (http://www.bibliotecanacionaldigital.cl)

The letter suggests her intention was to return to Chile in 1939. She had started the repatriation process, but, as she confesses to Mistral, the process was very slow and complicated, so she turned to her friend to hurry things up and bring about a speedy resolution. There are no further letters from this period but we can assume that the process was not successful and Zardoya had to remain in Spain. Whatever the case, in 1939 she returned to Madrid and, like many Spaniards in the harsh years of the 1940s she struggled to survive and keep her head above water: she taught, took in sewing, did some typing and attempted to complete her degree, although initially she resisted graduating from Franco's University (Rodríguez Pequeño, 1987: 45-46). This appears to have been the motive behind her delayed departure from Spain, according to a 
later letter to Mistral, sent from the United States (Urbana, 24 de Octubre de 1948): "I want you to know, I didn't come to the States before because I didn't want to graduate from the University of Franco; I waited and waited to see if things would change. My hope died last year. ${ }^{11}$ " (http://www.bibliotecanacionaldigital.cl).

If her life as an exile officially began in 1948, she embarked on her inner exile in 1939. Post-Civil War Spain was, as she eloquently described many years later, "a cemetery or corral where / days and dreams, and nostalgias rot. / The doors and windows are closed / to the blue sky, without a glance" (1965: 85). At the end of the war, she was surrounded by a desolate landscape: ruins, destruction and improvised concentration camps built to house Republican prisoners who would soon be transferred to the appalling Francoist prisons. It was a ghostly space in which "the living and the dead become confused / in Spain's sad corral" (1965: 86). The armed conflict may have officially ended, but the regime of terror continued until the end of the 1940s; the state of war declared on $18^{\text {th }}$ July 1936 was not lifted until 1948 . All those who had defended the Republican cause soon realised that in Franco's Spain such things as "pardon", amnesty or reconciliation did not exist, as the "Law of Political Responsibility of February 1939" made very clear. The only thing that mattered was a complete annihilation of the enemy. In his first end-of-year address on $31^{\text {st }}$ December 1939, Franco placed special emphasis on the repressive line that was to be followed by the judicial system of the dictatorship:

It is necessary to put an end to the hatreds and passions of our recent war but not in the manner of liberals, with their monstrous and suicidal amnesties, which are more fraud than pardon, but rather with the redemption of sentences through work, with repentance and penance. Anyone who thinks otherwise is guilty of irresponsibility or treason (Qtd. in Preston, 2012: 472).

Thus, the defeated Republicans who were not able to leave the country, and clearly stood outside of the Francoist legality suggested in the terms above, suffered grave consequences, being deprived of their most basic rights. In this sense, the repressive policy of the regime could be categorised as a flagrant negation of citizenship for one sector of the population. A brief overview of the four fundamental components demonstrates the extent to which the most basic rights of the victims of the dictatorship were taken away:

First, citizenship is a matter of formal legal status, as with the passport one holds. [...] Second, citizenship is a matter of rights - at an earlier stage, civil and political rights (e.g. to own property and to vote), and in the later Marshallian (1950) conception, social rights as well [...]. Third, citizenship denotes active engagement or participation in democratic self-governance. [...] Fourth, citizenship has a subjective component that captures people's sense of identification and solidarity. (Bartram et al, 2014: 34)
Within the context of the Franco regime and before the war had officially ended, the aforementioned "Law of Responsibilities" sanctioned all those who had fought for the Republican cause in accordance with the four basic principles outlined here. From that moment they were almost surgically removed from the communitarian "we" and became "they," the "reds." This fact questions the extent to which institutional ostracism of one sector of a population-who had their property confiscated, who were subjected to political purges in which they were forced to give up their jobs (particularly in the public sector), and who were deprived of participation in public life - can therefore be considered a (material) form of exile, or, in other words, of expulsion from society. In her moving epigraph to Corral de vivos y muertos, Zardoya frames her political protest as follows: "With the hope of gaining a painful citizenship that others deny me," which suggests the primary reason for her inner exile and later her exile from Spain.

It is, however, worth mentioning that here the use of the label "inner exile" differs from the criteria proposed by Paul Ilie in Literature and Inner Exile (1980): the present study emphasises the historical anchoring of the case rather than a mental condition or psychological state. Although the term is an oxymoron and therefore flirts openly with the figurative dimension of the concept that has provoked so much reservation among critics, the use of inner exile here is linked to the ideas defended by Paul Preston in the final chapter of his book The Spanish Holocaust. Inquisition and Extermination in Twentieth-Century Spain (2011). ${ }^{12}$ Entitled "Franco's investment in terror," the chapter alludes to the exceptional historical conditions that devastated the civil population during those years of State terror, violence and generalised fear-referred to by Jordi Gracia (2004) as the "aesthetic of fear"- because, in the case of Francoism, the peace of the 1940s was an "uncivil peace" (Casanova, 2013), a farce, "disguised / by lying paper and ink", according to the words of the poet, Ángela Figuera (1986: 114). It is within the context of this exceptional post-war period, which threatened the most basic rights of some of its (defeated) citizens ${ }^{13}$ that Zardoya wrote Pájaros del Nuevo Mundo (1946), Dominio del llanto (1947) and Corral de vivos y muertos (1965). Significantly, the poems included in the section "En las sombras acechan" (Waiting in the Shadows) of this last collection, - an echo perhaps of Hernandez's El Hombre acecha (Man Lies in Wait)?"were written in Madrid between 1939 and 1947. Some formed part of the book Dominio del llanto, which were suppressed for obvious reasons of censorship" (Zardoya, 1965: 23). Therefore, these three books could be considered clear examples of a literature of inner exile. This applies even to the first of them, which, despite the allegorical camouflage with its escapist appearance (intended to avoid censorship), denounces the lack of freedom suffered by Spanish society, silenced by fear (Bellver, 1991: 55): "Desolation. Tears. Prison. These are the feelings that appear in this book" (Fagundo, 1995: 186). Linked to these feelings are the aforementioned poems in the sec- 
tion "En las sombras acechan" in Corral. The first of these describes the atmosphere of desolation, of permanent pain in which a sector of the population lived during the first post-war decade: "a defenceless beating, / a death, day to day, / in a country of grief" (23). And pain is combined with fear: in this panoptic society suspects are closely watched so they can later be reported. In fact, the dictatorship exercised such extreme measures of control in civil society that anyone who did not demonstrate enthusiastic support for the regime could be accused of being a suspect. ${ }^{14}$ Passivity was therefore also sanctioned. Thus, in the last verse, the poetic voice exclaims "But the worries are in vain: the malevolent spies / lie in wait in the shadows" (23).

For the defeated, it was as if the reality which they had been part of as citizens had been completely erased. This is the theme of "La realidad no existe" (Reality does not Exist): "reality does not exist / in this bloody today, / or in the old word. / [...] Reality? In the mud / the buried hate, / is non-existent or dies" (24). The verses The verses express most succinctly the loss, the loss of cultural and political identity that has been buried beneath a layer of rancour which, in these new conditions, leaves them invisible. Other poems, such as "La máscara" (The Mask), "Debajo del estiércol hay raíces" (There are Roots beneath the Manure) and "Triste verdad" (Sad Truth) allude to this idea of hiding grief and feelings of loss by participating in ritual gestures (or social performance). Beneath the moral misery, now part of people's daily routine, another truth can be discern: "beneath the manure there are roots / that slowly rise, that work / on a black horizon of humidities, of putrid sadness, towards the dawn" (1965: 12). This truth is hidden, on an individual level, beneath the skin, beneath the pretend happiness that is necessary in order to continue living: "beneath the actions, the laughter, / the smallest gesture, sweet and light. / In the smallest pleasures and happiness, / that pain without tears, is felt" (1965: 14). And so the poetic voice declares that "the truth pains us like a thorn / that nobody can remove, only death" (1965: 14).

This persistent feeling of alienation, of feeling estranged in your own home, is what has come to be known as inner exile. The agonising distress present in Zardoya's poems can be understood further when read in light of the moving testimony by the poet Ángel González as he recalls the surprise, and not only the spiritual but also the physical displacement that he experienced in the post-war period in his native city of Gijón. Despite the inherent contradictions of inner exile, he defends it as the most appropriate term to express the terrible feeling of strangeness that the new Spain, lauded in the hymns of the victors, caused in the defeated Republicans:

If, as I believe, one of the ingredients of exile is strangeness, which is what I felt towards the country that gave me the final moments of the Civil War and the subsequent long post-war years, it could not have been any less than those passengers on the Sinaia or the Winnipeg must have felt when they disembarked on the, then un- known, remote coasts of America. When Franco's peace had been established definitively in Oviedo [...], the city in ruins I contemplated in 1938 and 1939, couldn't have been more alien, less mine, or in short, more strange. It's true that I hadn't been expelled from the place, but somehow they had snatched it away from beneath my feet. An invisible border, the deep trench of war turned that city, the whole country, into a remote region that was beyond reach (González, 1991: 197).

This strangeness in the face of reality and the nostalgia for a lost world is shared by both inner and territorial exiles and is present in both Corral de vivos y muertos and Desterrado ensueño. The two works are products of exceptional historical circumstances; in fact, the paratexts which frame both books situate them in the world and remind the reader of the unavoidable perspective of wordliness from which they were written. I have already mentioned the significant epigraph that frames the poetic discourse in Corral, in which Zardoya attempts to achieve a citizenship that has been taken from her, not only because her Spanish nationality is not recognised by some, but also because she has been deprived of her civil rights. Desterrado ensueño also opens with a moving dedication ("To all the Spaniards exiled in a single love") and, as she explained to the exiled poet Jorge Guillén in a letter dated $3^{\text {rd }}$ December 1953, it is a book for those outside of Spain:

And then, that incurable wound that Spain caused us that cannot be healed. One day I will send you my last book, born from the pain of Spain: it's called El desterrado ensueño. It moved Vicente Aleixandre and José Luis Cano who have both read it. Cano wants to publish it in Ínsula but I'm not convinced. However, the book isn't written for those who live in Spain, but for those who left, for the exiles, and that's the reason for the title of the poem in the prologue (BN de España; archivo personal Jorge Guillén 102/32).

The book was finally published by the Hispanic Institute in the United States, not by Ínsula. In the prologue referred to in the letter by Zardoya, three fundamental principles are established which frame the rest of the poems in the book. The first is the state of being neither there nor here, (here means USA, the present and the space of the writing; there means Spain, the space of memory) which brings the work close to what could be described as border writing: "today we are crying / between heaven and earth" (9). The tension between these two spaces (here-there; heaven-earth) can be seen in the juxtaposition of the first sections of the collection, "Las ciudades" (The Cities) and "La sombra detenida" (The Detained Shadow), which evoke a cinematic image of nostalgia, as they produce "a double exposure, or a superimposition of two images - of home and abroad, past and present, dream and everyday life. The moment we try to force it into a single image, it breaks the frame or burns the surface" (Boym, 2001: xiv). In Zardoya the frame is never broken because the dreamlike states do not allow it. The second aspect — closely linked to the first — relates to 
the evocation of lost space through the poetic gaze. The third responds to the desire of the poetic speaker to recover the innocence of childhood in order to inhabit these evoked places, cancelling or erasing the devastating effects of history.

There is, however, a great difference between Desterrado ensueño and the later Corral de vivos y muertos as regards the treatment of the theme of exile: whilst the first exhibits a narcissistic introjection, the second develops an ethical and collective dimension that seeks a profound communication with the other. ${ }^{15}$ The reconstruction of lost space in Desterrado ensueño is produced, therefore, as an exercise in personal survival; for the writer, exile was simply "a living ulcer in her spirit" which could never fully heal, not even with her return to Spain in 1977. In the first stage of her exile, therefore, the remembrance of Spain and its cities, Ronda, Granada, Cordoba, Toledo, Madrid, Zamora, comes from an overwhelming need to physically recover a geographical and cultural reality that distance seemed to have completely erased; but the perspective from which this ephemeral meeting is viewed is clearly personal. The meditative tone of Zardoya to some extent resembles that of William Wordsworth in Lyrical Ballads and his "picture of the mind:" what she preserves of the remembered landscape is nothing more than "sensations transferred to their "most pure' spirit" (Guillén, 2007: 147). However, in contrast to Wordsworth, this evocation of the landscape of her youth from a distance unleashes its own internalisation (Fagundo, 1995: 195), as if it formed part of her body. This process begins in "Como una gran ciudad, España mía" (Like a great city, my Spain), in which the homeland she left behind is miniaturised and becomes an island: "like an island, you, are in my blood / and search for the port of my soul / where a lighthouse-you-always shine / you continue afloat in that ocean!" (13). The affective value of the miniature, of the smallhere Spain is a mobile, diminutive homeland, the size of a cell that runs through her veins-has been explored by French philosopher Gaston Bachelard in The Poetics of Space. For Bachelard, the distance that separates the landscape from the subject who contemplates it "creates miniatures at all points on the horizon" (172). This shrinking process, however, does not produce dispersion, but on the contrary possession and reunion:

\footnotetext{
The isolated villages on the horizon become homelands for the eyes. Distance disperses nothing but, on the contrary, composes a miniature of a country in which we should like to live. In distant miniatures, disparate things become reconciled. They then offer themselves for our 'possession,' while denying the distance that created them. We possess from afar, and how peacefully! (172).
}

This is what happens in the aforementioned poem, in which the distance of exile in both its spatial and temporal dimensions reunites the dispersed landscape of Spain in a great city which subsumes the country as a whole, and which acquires the size of a tiny island that travels inside the body and spirit of the poetic speaker evoking it. Yet, Zardoya's constant use of interrogation often calls into question this final act of possession and reunion described by Bachelard; she knows that the conquest of space is transitory, a product of memory (poetic recall) and that opening her eyes means returning to the spatial reality of her life in the USA: "to live, live in dreams? / or to wake, finally, in another life." Furthermore, Zardoya is also aware that the loss of the Spanish landscape goes hand in hand with the loss of her cultural world. Proof of this can be seen in the elegies she dedicates to Garcilaso, San Juan de la Cruz, Quevedo, Bécquer, Unamuno, Machado: "with the possibility of being in Spain physically, the writer projects her desire through her writing, to at least feel a spiritual part of the place she considers her place of origin and in which she encodes the beginnings of her identity" (Moreno, 2009: 129).

\section{ACTS OF AFFECTIVE CITIZENSHIP}

The intersection between citizenship, exile and woman has been studied in detail by Pilar Domínguez Prats (2009) in De ciudadanas a exiliadas: Un estudio sobre las republicanas españolas en México. In this work, the author reminds us that citizenship was a subject left pending for Spanish exiles for almost six decades. This was something that was not addressed until much later when, in the so-called "year of historical memory" in 2006 and thanks to the first proclamation of the Statute of Spanish Citizenship abroad, their rights were finally guaranteed (22). The oral testimonies which form the basis of this decisive work document the efforts of many Republican women in Mexico who were in solidarity with those trapped in Franco's Spain, despite having lost their own Spanish citizenship. In this sense, they carried out acts that will here be called "affective citizenship" (Gregorio \& Merolli 2016; Fortier 2016) insomuch as it "focuses on one aspect of how citizenship 'takes place' by emphasising how it is affective-how it involves emotions, feelings, bodies" (Fortier, 2016: 1040). The concept of "affective citizenship" used in this essay refers, therefore, to the practices of "radical inclusion" that serves to undermine the power of the Francoist dictatorship in its desire to define and control the population. These practices decentre the concept of citizenship; they transcend the spatial caesura of exile, creating bonds of solidarity that allow the sharing of similar feelings. Affect, therefore, in this context becomes "a site of resistance and political possibility" (Gregorio \& Merolli, 2016: 934).

For Concha Zardoya, the tragic events of the Civil War consolidated the acquisition of a citizenship that, until that point, had been just a part of her cultural identity. The previous section made reference to the painful expe- 
riences she endured during the war that were the catalyst for the writer's vision of the world and of humankind that she would develop shortly afterwards in her poetry and literary criticism. This can be seen in a letter to Gabriel Mistral dated $31^{\text {st }}$ January, 1951:

\begin{abstract}
I also wonder what citizenship I retain. I have Spanish citizenship, as the authorities only consider the citizenship of origin valid and pay no attention to the place of birth in their racist desire to boost the country's population. On the other hand, although I still love Chile, the pain of the Civil War and the post-war, the loss of loved ones and other spiritual values, have tied me forever to Spain, even though I cannot live there now and I've had to come to a country I don't understand [...].

(http://www.bibliotecanacionaldigital.cl)
\end{abstract}

Zardoya's words, therefore, set out a definition of the concept of citizenship as an affective act, in which the notion of affect forms an integral part of a politics of identity and resistance. ${ }^{16}$

It is Margaret Persin (2014), however, who has examined more closely the problematical conceptualization of the term citizenship in Corral de vivos y muertos. As well as the three usual models of citizenship - civil, political and social—Persin adds a fourth: the performative. With this, and using the theories of Judith Butler relating to gender as performance, ${ }^{17}$ she proposes a model of citizenship "imposed from outside by means of repeated acts that result in the silencing of dissident voices" (85-86). This is the model employed by the Franco regime, set out in the famous Law of Political Responsibilities. At the opposite extreme there is the model defended in Corral de vivos y muertos:

In her poetry she extends the limits of citizenship beyond those proclaimed by the political establishment, with its patriarchal foundation, to be sure. And by means of advocating for the legitimacy of citizenship for marginalised groups, she inserts specific spaces into the historical discourse of post-Civil War Spain, thus contributing to the subversion of the binary opposition of time and space, in addition to that of the masculine and the feminine (78)

To this list of binaries we should also add that of inside/outside, since, in contrast to the intimate treatment of exile developed in Desterrado ensueño, the ethical dimension of Corral comprises, firstly, an attempt to blur the line that separates the private sphere of internal beliefs and the external obedience required by the state (Gregorio \& Merolli, 2016; 934). Secondly and closely linked to this aspect, the ethical dimension recognises the existence of a political and cultural community or brotherhood which transcends geographical distance: those who left and those who stayed behind are the same Spain. For this reason the structure of the book juxtaposes poems which deal with the suffering experienced by both groups as well as problematizing the mutual affective distance caused by the spatial rupture. This growing distance makes future reconciliation challenging but not impossible. The poem "Entre vivos y muertos" (Neither alive nor dead) reflects this malaise:

They are suspicious and mistrusting, those inside.

Neither do we trust those outside.

Nobody believes in the other and it's not true,

that they can trust. The air is lying in wait.

One fears the dialogue of the wind.

It drags, weakly, their conscience,

their sad vegetation, silent mud.

Their terror is masked by the control.

The accomplices are loathed: their fear

is a vulture that attacks without shame.

They make accusations in passing or in silence

those unfortunates who wander strange lands.

Neither alive nor dead, let's conquer

good faith, coexistence! (17)

Unfortunately, as the years went by, exile began to assume a more permanent quality, as did the political structures of the dictatorship. The spatial separation then began to be seen as a spiritual distance caused by mutual mistrust and resentment. Zardoya suffered this excision intimately as she was aware of the suffering of both sides from personal experience. She had lived the hardest years of the post-war period with their hunger and misery, but above all, fear. And she had also lived through the absence and nostalgia of exile. The poem lays out all these tensions: those who left accuse those who stayed behind of complicity with the regime, and those who stayed reproach those who left for their cowardly escape. However, the concept of affective citizenship which underpins in the book demonstrates not only the acquisition of certain rights, but also the observance of certain responsibilities, movingly described in the last verse of the poem: "Neither alive nor dead, let's conquer / good faith, coexistence!" A similar message can be found in the last two poems that make up the final section of the book, "Sólo tu luz, España, reluciente" (Only your light, Spain, shining) in which the interrogated "you" is Spanish society in its totality (inside and outside of the geographical borders):

With our hands - one! — we will wash

the war from the floor and with your wine,

with the salt from your beaches, with your snow

The land will shine like a mirror:

there will be no shadows of old signs

only your light, Spain, shining! (142)

Nonetheless, Zardoya knows this necessary coexistence, a fundamental element of affective citizenship that is present in the verses of Corral, will not begin until the mask that hides the policies of terror is removed from the dictatorship: "This is not a cross of love.... To tear it down / the dead must be brought together in their graves" 
(90). There are numerous poems which offer a true depiction of the post-war years: the hunger that devastated the whole population, but the childrren in particular who were robbed of her children, and which is described in the section "Retablo del hambre" (Altarpiece of Hunger); the pain of the political prisoners illustrated in the poem "En la reja de hierro se ha posado" (Placed in the iron bars) or the execution squads who were responsible for continuing the war during peacetime in "Yo me miro crecer en estos muros" (I watch myself grow in these walls): "Who makes the white cemeteries bigger / with the graves open every night?" (25). All these poems are acts of affective citizenship which facilitate the creation of a "counter-discourse and a vision of a possible Spain that both rejects the extremes of Francoism and reintegrates the longed for values of community and patriotism [...]" (Persin, 2014: 79). It is no surprise that, at the time, the book could not be published in Spain and it had to be published in Buenos Aires. Censors would not have been very happy with a work that laid bare the moral misery of a time in which the political regime covered up injustice with great military parades, annual victory celebrations - at the same time a reminder of defeat for the other half of the population - , and their propaganda of peace and progress. Years later, in her critical essay "El poeta político" (The political Poet), Zardoya theoretically formulates what she had already set out in the lyrical discourse of the poem:

The poet cannot be a solitary being: their "I" has become a "we." They aren't just witnesses to their own social environment but their own hearts beat with that of others. The "otherness" - the others - shape them as much as their own individuality. Their poetry, therefore, is both a personal and collective experience $(1976: 140)$

Although, with these words the writer wanted to contextualize in her essay the civic poetry of Miguel de Unamuno, Antonio Machado, Rafael Alberti and Miguel Hernández, ${ }^{18}$ it could also be argued that this same description characterises her own literary career. The evolution which took place in her work from Desterrado ensueño to Corral de vivos y muertos and Hondo sur was a journey from an "I" to a "we." Indeed, the poetic voice in the last two books is not just a simple witness to the reality of a social environment but an active member of a community. In this sense, there is a unique parallelism between some of the poems in Corral (and to an extent many of those in Hondo sur as well) and another collection which is also the result of the experience of exile: Primavera en Easton Hastings (Spring in Eaton Hastings) by Pedro Garfias. This book has been described as an "act of ethical determination, in which the subject does not conceive the other person who is absent as an object, but recognises them as his addressee, in their irreducible distance, to whom they show themselves" (Barriales-Bouche, 2008: 195-196). The texts in Corral and Hondo Sur are also an act of ethical determination in which, on many occasions, the civic song adopts the form of an elegy (which incidentally also occurred in Garfías's work). The following lines express the collective sorrow that runs through the poem and set out the mission of the poet/intellectual:

I watch myself grow in these walls

like a willow without beneficent water,

living my destiny in defeat

crying to the dead and the orphaned (Corral 1965: 25).

In this poem the image of the walls indicates both the emancipatory and exclusionary potential of an affective citizenship. On one hand, the Franco regime rules through affect, instigating fear and expelling difference (something that Persin called performative citizenship). On the other hand, affect can be used as a tool with which to fight and bring about transformation in the sense that it can "produce and build political identities outside of the state" (Gregorio \& Merolli, 2016: 934). In reality, what we are talking about here is the presence of "atmospheric walls" - in the words of Benedict Anderson $(2009$, 2014; qtd. in Gregorio \& Merolli, 2016: 936) - that denote the experience of imprisonment and isolation endured by the post-war society (Richards, 1998: 7-26). This is also illustrated in "Cementerio de vivos" (Cemetery of the Living) in which national space is identified as a large cemetery. Zardoya had borrowed the image from the poetry of Unamuno, more precisely, from composition no. 680 of his Cancionero: "Cemetery of the living / a prison with no locks, Spain / the living unconfined - not alive / or free-dragged by fortune" (qtd. in Zardoya, 1976: 159). Zardoya was familiar with Unamuno's poetry and had included him as one of the protagonists of her essay "The Political Poet." Talking about Cancionero, the source of inspiration for her own poetry, she referred to it as "a compact tragic synthesis of Spain, of her yesterday and her present" (159). Moreover, Zardoya knew very well that the Spain-cemetery of Franco was the legitimate inheritance of this same obscurantist, regressive tradition to which Unamuno referred in his poem. As she also declared in another of her poems, Spanish society found itself "separated from the world by a grave / of outmoded tradition, sad Spain, / of regressive strengths, stiff mud / that dry the seeds in the plowland" (1965:14). Isolation, silence, and enclosure would become key themes in post-war Spanish literature, such as in the case of Eugenio Nora's Pueblo Cautivo (Captive People), Ángela Figura's poem "Puentes" (Bridges) from Belleza Cruel (Cruel Beauty), or Luis Martín Santos' novel Tiempo de silencio (A Time of Silence). The act of affective citizenship represented by Corral, however, proposes breaking down these (atmospheric) walls with the aim of creating "a new sense of community that is open to and based in difference, but also serves as a radical critique of the assimilatory logic of state-based identities" (Gregorio \& Merolli, 2016: 938).

As this new sense of community is created, the poetic voice subverts, in this way, the Francoist triumphalist dis- 
course, and in exchange, evokes the image of cemeteries and graves - death, absence, putrefaction-from which a new future and a new history will emerge: "beneath these tombs there are seeds / of a new future and a new history. If we move the stones we will find / resounding active rebellion" (1965: 52). This time, the image of the graves and the cemeteries are associated with a positive sentiment, something which also occurs with the theme of ruins in Zardoya's poetry (as can also be seen in Hondo sur):

The rebellion of the ruins

Let the ruins rebel

From the depths of time!

The past against today,

in a silent battle!

The tower of homage,

stone, we must build once more:

with mortar and ardour,

with grey dust and with dreams

—builders of hope-

with pain and valour.

No more defeated battlements

in the rock castles!

Let the rocks be spears,

hearts and deep breath!

the past against today

in silent rebellion! (1965: 60)

The ruins are traces of a past that has survived destruction and whose presence will destabilize the control of the social space exerted by the present, the "today" of the dictatorship. Static and silent, the ruins are the foundations of another reality which must emerge from the historic agency of a community that reclaims their citizenship "with mortar and ardour [...] / with pain and valour." In this way, Zardoya's verse echoes the reflections of fellow exile, the philosopher María Zambrano in Delirio y destino:

\footnotetext{
Ruins are what live on most from history; historically it is only that which survives destruction that lives, that which has been left in ruins. And so, ruins would give us the point of identity between personal living - personal history-and history. It is the person that survives the destruction of everything in their life but still allows us to see how, from their own life, a superior sense towards events gives them an added significance, bringing them together in one image, the affirmation of an enduring freedom through the imposition of circumstances, in the prison of situations (1993: 313).
}

Zardoya also survived the devastation of everything in her life: Civil war and exile destroyed her home, family ties, friendships. The ruins that Zardoya refers to were all that were left on which to build her affective citizenship.

\section{THE INTELLECTUAL EXILE: CONCLUDING REMARKS}

If it was difficult to reconcile history and metaphor in the concept of exile formulated by critic Edward Said in his theoretical discourse, the literary journey of Concha Zardoya shows just the opposite. In Desterrado ensueño and in Corral de vivos y muertos the committed intellectual inside her was awakened by the experience of exile, an intellectual who, after living in the south of the United States for ten years, could no longer remain silent about the racial injustices she witnessed on a daily basis. She was also "a sensitive antenna for political and social history" (Zardoya, 1976: 143) of the country in which she had to endure her exile.

Zardoya arrived in New Orleans at the beginning of the 1950 s to teach language and literature at the University of Tulane. Her stay coincided with the most active period of the African-American Civil Rights Movement (1954-1968) whose aim was to put an end to legalised racial segregation and discriminatory laws. Hondo sur (1968) was the result of her contact with this reality, and was "unusual in Spanish poetry" both for its themes and its poetic beauty (Moreno, 2009: 137). In the book, the writer demonstrates her intimate knowledge of southern US traditions and culture. For example, one of the sections consists of a collection of southern proverbs in English that are annotated and explained in a series of lyrical compositions. The book also gathers several snapshots of the places she had visited, almost as if it were a travelogue in which she recorded her immediate impressions of the mansions, plantations, ruins and cemeteries she came across. However, the book, as the writer herself admits in the prologue, was written "in absence and through memory" (in California, New York, and Indiana), as in the verbal recreations of landscape included in Desterrado ensueño. But, despite the similarities, Hondo sur is exempt from the solipsism that characterised the earlier collection. Although Zardoya says in the prologue that "the South of the USA is the heart of these poems, but the true protagonist is my soul, the mirror through which that world is reflected, sometimes beautiful, sometimes sad, at others unjust and cruel" (9), the volume is characterised by the same ethical approach as Corral de vivos y muertos: "and I wanted to stand with the southern man-white and black - and express in my own way my human indignation or my solidarity with his suffering" (9). For that reason, in the composition that opens the volume, the poetic voice extends the civic song of Corral to the victims of slavery (in the past) and of racial discrimination (in the present) to lament a seemingly endless injustice:

Must I weep in song for what has happened in Southern lands for so long?

Denounce the silence of this century, the cruelty or the disregard of the whites? Intensify the rancour or the patience?

The deep South, here, in its beauty, its pain, my pity, in all its clarity! (11-13) 
It is clear that compositions such as "Ida Turner," "Condena en Mississippi," (Condemnation in Mississippi), "Freedom Riders" (dedicated to Andrew Goodman and Michael Schwerner assassinated in Mississippi), "Ode to Martin Luther King" and "Crucifixion in Texas," display her political evolution as an exiled intellectual in Said's terms: they are all texts that clearly "speak truth to power," and that are, without a doubt, "worldly," as they form part of the historical moment in which they are situated. But, as Zardoya herself said, none of this would have happened without the triggers of the Civil War and subsequent exile, which were the cause of her "vision of the world and of man." The tragedy in Spain opened her eyes to pain. "Crucifixion in Texas" gives us an insight into this kind of déjà $v u$ experienced by the poetic voice in the face of the violence suffered by African Americans in Texas. She sees the reappearance of the shadow of hatred that took so many lives during the Civil War and the immediate post-war period. Once again she turns to interrogation to set out a utopian solution to a conflict that will only be possible once the borders of race (in Corral these were political walls) and hatred have been removed:

\author{
Do you offer comfort with your arms? \\ In a sea now without tears, \\ the ship of your cross \\ slowly glides along: \\ towards the shores of love, \\ without borders of race, \\ without the compost of hatred \\ that severs and crucifies? (162-166)
}

These lines mark the end of her journey from "I" to "we" because, according to Zardoya, the poet/intellectual has no choice but to assume an ethical position. She returned to this aspect insistently in the short poetic manifesto entitled "The Leaning Tower," an essay written much later, almost at the end of her life, in 1986, when she had retired and had settled permanently in Spain. In this work, she offers a number of significant insights in line with her previous literary criticism and poetic practice, and proclaims finally, that "poetry is an act of faith;" the only thing that can speak truth to power:

So, above and beyond tendencies and convictions, men and women who believe in Poetry are willing to defend it in all its valid forms [...]. In the world today Poetry cannot be relegated to a place apart. To achieve its mission, it should adopt an active position, uniting and unifying all countries in a common act. Among all the inventions and metamorphoses of our time, Poetry - as a universal language, in spite of the many languages in which it is expressed-should perform its efficient and indispensable role (45).

Only the universal language of poetry defended here by Zardoya could have articulated the acts of affective citizenship seen in Corral de vivos y muertos and Hondo sur, examples of a persistent fight against injustice, dispossession and the ruthless exercise of power. Only poetry, understood as an act of faith in humankind, is capable of transcending all types of borders.

\section{NOTES}

1 This article has been written with the generous support of the Leverhulme Trust which is funding the three-year project Inner and Outer Exile in Fascist Germany and Spain and Spain: A Comparative Study (2016-2019).

2 Despite Mercedes Rodríguez Pequeño's monograph (1987) and the respective critical studies on Zardoya by Biruté Ciplijauskaité (1978; 2002), Catherine Bellver (1991), Andrew Debicki (1994), Janet Pérez (2007; 2009), Mari Paz Moreno (2009) and Margaret Persin $(1997 ; 2009 ; 2014)$, there is no mention of her work in the now classic studies of post-war Spanish poetry such as those by Manuel Mantero (1986), $\mathrm{M}^{\mathrm{a}}$ del Pilar Palomo (1990) or Víctor García de la Concha (1992). Further proof of the imbalance in the recognition of her work is her absence in the rigorous Historia de la literatura española by Jordi Gracia y Domingo Ródenas (2011).

3 She was a regular contributor to the Spanish journals Ínsula and Índice. She also occasionally contributed to Revista de Occidente and Papeles de Son Armadans.

4 According to Catherine Bellver, which draws on Paul Tabori's The Anatomy of Exile, the main difference between exile and expatriation lies in the fact that the latter "is not a response to expulsion but rather a voluntary separation frequently chosen in the name of artistic freedom" (58). For Bellver, the poets Concha Méndez and Ernestina de Champourcín would fall into the category of exiles, while Concha Zardoya would be an expatriate. However, she immediately adds that "the strictness of Francoist authoritarianism meant that political reasons were present in Zardoya's decision to leave the country even if not with the same urgency then certainly with the same importance as the other two writers" (58). This clarification leads Bellver to conclude that "the distinctions between exile and expatriation are void as it is in Zardoya's work that the theme of exile appears with more nuance and insistence" (58). My contention is that Zardoya is an exile, not an expatriate. See Edward Said (1984), Michael Ugarte (1999), Sophia McClennen (2004) and Mari Paz Balibrea (2017) for further discussion on the semantics of the concept of exile.

5 In contrast to other studies that have approached the theme of exile in Concha Zardoya's poetic work, such as the aforementioned Catherine Bellver (1991) or Mari Paz Moreno (2009), my focus is distinctly historical. Both authors turn at a certain moment of their analysis to ontological exile to explain the creative process from which Zardoya's poetic world springs. According to Moreno, "writing in itself would be an exercise in self-exclusion and the exiled poet would be excluded not only from her country of origin in a geographical sense, but also in a metaphorical sense, from the place that makes up the centre of her existence" (127)

6 All texts originally in Spanish translated by Jennifer Arnold.

7 Said's theories are framed by his rejection of the concept of textuality as understood by structuralism and post-structuralism: "For Said, post-structuralists virtually reject the world and allow no sense of the material worldliness of people who write texts and read them, cutting off the possibility of political action in their theory" (Ashcroft and Ahluwalia: 7).

8 "El niño yuntero," "Canción del esposo soldado," and "El sudor" belong to the collection Viento del pueblo (1937) and "Madrid " is included in El hombre acecha (1938)

9 She dedicated a monograph to his poetry, Miguel Hernández. Vida y obra, as well as various studies included in Poesía espanola contemporánea: estudios temáticos y estilísticos and in "El poeta político (En torno a España)."

10 Thought to be from 1939, although no year is included in the letter. 
11 This wait to which Concha Zardoya alludes here relates to hopes of an allied victory. Many Republicans believed that the fall of Fascism would cause the Franco regime to unravel. Unfortunately, as is well known, these expectations were never fulfilled.

12 The label "inner exile" has had its detractors since Ilie's book (1980) offered a definitive definition. Naharro-Calderón (1994), Faber (2006), Aznar Soler (2008; 2007), Gracia (2009), López García (2008), among others, coincide in pointing to the negative effect produced by the term because "once we allow ourselves to think of exile in existential or figurative terms, there is little that would automatically fall outside of the field's scope" (Faber: 13).

13 In fact, as José María Naharro-Calderón explains, the experiences of the Spanish post-war period do not correspond to what is normally understood by the term: "Generally we associate the idea with a period in which hostilities between two or more opposing sides cease, giving way to a different dialectic of the antagonist. Yet it is well known that, historically, the Spanish 'post-war' was not a peaceful model, nor did it represent a period of healing acceptance. On the contrary, it was one of exclusion and absence, $[\ldots]$ ". (88).

14 According to the famous Law of Responsibilities: "The political responsibility is declared of all those persons who, after 1 October 1934 and before 18 July 1936, contributed to the creation or aggravation of the subversion of any kind of which Spain was made a victim, and of those others, who from the second of said dates have opposed or might oppose the National Movement with concrete acts or serious passivity" (qtd. in Preston: 503).

15 In this sense Zardoya's poetry initiates an interesting and close parallelism with the experience of exile Pedro Garfías in Primavera en Eaton Hastings. See Sandra Barriales-Bouche (2008).

16 According to Fortier, "the term affect [designates] a generic category of emotions and feelings, including embodied and sensory feelings through which worlds, subjects and objects are enacted and brought forth" (1039).

17 According to Butler, "the action of gender requires a performance that is repeated. This repetition is at once a reenactment and reexperience of a set of meanings already socially established; [...]" (Butler: 140. Qtd. in Persin, 2014: 76).

18 Zardoya also includes the Latin American poets Cesar Vallejo y Pablo Neruda, who also wrote about Spain in their poetry.

\section{REFERENCES}

Ashcroft, Bill y Ahluwalia, Pal (1999) Edward Said. Routledge, London.

Aznar Soler, Manuel (2008) "Los conceptos de 'exilio' y 'exilio interior'". En El exilio: debate para la historia y la cultura, ed. Ascunce, José Ángel. Saturrarán, San Sebastián: 47-61.

Bachelard, Gaston (1994) The Poetics of Space. The Classic Look at How We Experience Intimate Places. Translated by Stilgoe, John R. Beacon Press, Boston.

Balibrea, Mari Paz (2017) Líneas de fuga. Hacia otra historiografia cultural del exilio republicano español. Siglo XXI, Madrid.

Barriales-Bouche, Sandra (2008) "La dimensión ética de la poesía en el exilio: Primavera en Eaton Hastings de Pedro Garfias". Hispanic Review, 76: 179-196. http://www.jstor.org/stable/27668836. Access 11-01-2018 01:16 UTC

Bartram, David, Poros Maritsa V. y Monforte, Pierre (2014) Key Concepts in Migration. Sage Publication, London.

Bellver, Catherine (1991) "Tres poetas desterradas y la morfología del exilio". Letras Femeninas, 17: 51-63. http://www.jstor.org/ stable/23022022. Accessed: 11-11-2017 01:03 UTC

Boym, Svetlana (2001) The Future of Nostalgia. Basic Books, New York.

Ciplijauskaité, Biruté (1978) "Dos casas habitadas por la ausencia". Sin nombre, 9: 32-40.
Ciplijauskaité, Biruté (2002) "La poesía es un ser y nunca un comprensión”. Salina: Revista de Lletres, 16: 187-192.

Debicki, Andrew P. (1994) Spanish Poetry of the Twentieth Century. Modernity and Beyond. University of Kentucky Press, Lexington.

Di Gregorio, Michael y Merolli, Jessica L. (2016) "Introduction: affective citizenship and the politics of identity, control, resistance". Citizenship Studies 20: 933-942. http://dx.doi.org/10.108 0/13621025.2016.1229193 11 November 2017, At: 16:23.

Domínguez Prats, Pilar (2009) De ciudadanas a exiliadas. Un estudio sobre las republicanas españolas en México. Ediciones Cinca, Fundación Largo Caballero, Madrid.

Faber, Sebastiaan (2006) "The Privilege of Pain: The Exile as Ethical Model in Max Aub, Francisco Ayala, and Edward Said". Journal of Disciplinary Crossroads 3: 11-31.

Fagundo, Ana María (1995) Literatura femenina de España en las Américas. Fundamentos, Madrid.

Fortier, Anne-Marie (2016) "Afterwood: Acts of Affective citizenship? Possibilities and limitations". Citizenship Studies 20: 1038-1044. DOI: 10.1080/13621025.2016.1229190

Guillén, Claudio (2007) Múltiples moradas. Ensayo de Literatura Comparada. Tusquests, Barcelona.

Ilie, Paul. Authoritarian Spain, 1939-1975. Literature and Inner Exile. The Johns Hopkins University Press, Baltimore and London.

González, Ángel (1991) "El exilio en España y desde España”, en El exilio de las Españas de 1939 en las Américas: "¿Adónde fue la canción?», ed. Naharro-Calderón, José María. Anthropos, Barcelona.

Gracia, Jordi (2009) A la intemperie. Exilio y Cultura en España. Anagrama, Barcelona.

Gracia, Jordi y Ródenas, Domingo (2011) Historia de la literatura española. 7. Derrota y restitución de la modernidad, 19392010. Crítica, Barcelona.

López García, José Ramón (2008) "El concepto de exilio y la poesía de los exiliados republicanos de 1939". En El exilio: debate para la historia y la cultura, ed. Ascunce, José Ángel. Saturrarán, San Sebastián: 77-100.

Mantero, Manuel (1986) Poetas españoles de posguerra. Espasa Calpe, Madrid

McClennen, Sophia (2004) The Dialectics of Exile: Nation, Time, Language, and Space in Hispanic Literatures. Purdue University Press, West Lafayette.

Moreno, Mari Paz (2009) "Concha Zardoya y el exilio como espacio creativo: La poética de la memoria”. En Mujer, creación y exilio, eds. Jato, Mónica, Keefe Ugalde, Sharon y Pérez, Janet. Icaria, Barcelona: 125-143.

Naharro-Calderón, José María (1994) Entre el exilio y el interior: el 'entresiglo y Juan Ramón Jiménez. Anthropos, Barcelona.

Persin, Margaret (1997) "Reading Goya's Gaze with Concha Zardoya and María Victoria Atencia". Anales de la literatura española contemporánea, 22: 75-90. http://www.jstor.org/stable/ 27741349 Downloaded from 147.188.128.75 on Sat, 11 Feb 2017 18:41:07 UTC

Persin, Margaret (2009), "Mujer y ciudadanía: los casos de Concha Zardoya y Juana Castro". Lectora, 15: 117-134.

Persin, Margaret (2014) "Women and Citizeship: Poetry of Power, Time and Space". En Differences in Common: Gender, Vulnerability and Community, eds. Sabadell-Nieto, Joana y Segarra, Marta, Rodopi, Amsterdam-New York: 75-95.

Pérez, Janet (2007) "El exilio, Ítaca y el no-destierro". Ojáncano 31: 43-65.

Pérez, Janet (2009) "El exilio político femenino de la guerra civil española”. En Mujer, creación y exilio, eds. Jato, Mónica, Keefe Ugalde, Sharon y Pérez, Janet. Icaria, Barcelona: 17-47.

Preston, Paul (2012) The Spanish Holocaust. Inquisition and Extermination in Twentieth-Centuty Spain. Harper Press, London.

Richards, Michael (1998) A Time of Silence. Civil War and the Culture of Repression in Franco's Spain, 1936-1945. Cambridge, Cambridge University Press.

Rodríguez Pequeño, Mercedes (1987) La poesía de Concha Zardoya. Valladolid, Universidad. 
Said, Edward (1983) The World, the Text and the Critic. Harvard University Press, Cambridge, MA.

Said, Edward (1984) "The Mind of Winter. Reflections on Life in exile", Harper's, 269: 49-55.

Said, Edward (1994) Representations of the Intellectual. Vintage Books, New York.

Ugarte, Michael (1999). Literatura española en el exilo. Un estudio comparativo. Siglo XXI, Madrid.

Zardoya, Concha (1946) Pájaros del Nuevo Mundo. Adonais, Madrid.

Zardoya, Concha (1947) Dominio del llanto. Adonais, Madrid.
Zardoya, Concha (1955) El desterrado ensueño. Hispanic Institute in the United States, Madrid.

Zardoya, Concha (1965) Corral de vivos y muertos. Losada, Buenos Aires.

Zardoya, Concha (1968) Hondo Sur. El Bardo, Barcelona.

Zardoya, Concha (1976) "El poeta político (En torno a España)". Cuadernos Americanos, 3: 139-273.

Zardoya, Concha (1981) Diotima y sus edades. Ámbito Literario, Barcelona.

Zardoya, Concha (1983) "La torre inclinada (Poesía y ciencia)". Diálogos: Artes, Letras, Ciencias humanas 19: 45-48. 